ECS Transactions, 59 (1) 321-326 (2014)

10.1149/05901.0321ecst @The Electrochemical Society

\title{
Simulated biogas for nickel-based solid oxide fuel cells
}

Jianjun Ma, Cairong Jiang, Mark Cassidy and John T. S. Irvine

School of Chemistry, University of St Andrews, KY16 9ST, United Kingdom

Biogas is composed of variable gases including hydrogen, nitrogen and sulphur, with methane and carbon dioxide as the main components. The common ratio of methane to carbon dioxide is $60 / 40$ in volume and this high amount of methane causes carbon deposition when biogas is used in solid oxide fuel cells. To prevent carbon deposition, dry reforming, steam reforming or partial oxidation is the common method. In this paper, a nickel cermet solid oxide fuel cell was investigated with a simulated biogas based on $63 \% \mathrm{CH}_{4}$ and $37 \% \mathrm{CO}_{2}$, which was obtained by presuming $80 \%$ fuel utilisation and $25 \%$ recirculation of anode gas. Supplied with a $30 \mathrm{ml} / \mathrm{min}$ of simulated biogas, the cell generated a maximum power density of $856 \mathrm{~mW} \mathrm{~cm}^{-2}$ at $850{ }^{\circ} \mathrm{C}$. The cell ran stably at loads of $100 \mathrm{~mA} \mathrm{~cm}$, $300 \mathrm{~mA} \mathrm{~cm}$ and $500 \mathrm{~mA} \mathrm{~cm}^{-2}$ over a period of 16 hours at each level.

\section{Introduction}

Biogas is a readily available resource, attracting much attention in meeting the demand for renewable energy and the reduction of $\mathrm{CO}_{2}$ emissions. The composition of biogas varies according to place, time and biological process. The usual biogas is composed of $50-70 \%$ methane, $25-50 \%$ carbon dioxide, $1-5 \%$ hydrogen, $0.3-3 \%$ nitrogen and some other minor impurities(1-2). Recently, efforts have been made to convert the chemical energy of biogas into electricity in a clean and efficient way (3-5). Solid oxide fuel cells offer the opportunity of using biogas because of its fuel feasibility and high efficiency (6). However carbon deposition occurs in conventional nickel anode-based solid oxide fuel cells (5), which can be prevented by dry reforming (7), steam reforming (8-10), partial oxidation (2,11-13), or anode off-gas recirculation (14-15).

Biogas benefits from the presence of carbon dioxide to some extent as carbon dioxide is a good reforming agent and can promote internal reforming thereby producing hydrogen and carbon monoxide for electrochemical energy generation $(5,16)$. Shiratori (17) investigated the stability of a NiO-ScSZ anode in supplying a simulated gas $\left(\mathrm{CH}_{4}: \mathrm{CO}_{2}=60: 40\right)$, and he found that the cell was stable for 200 hours at $200 \mathrm{~mA} \mathrm{~cm}$ when operating at $900{ }^{\circ} \mathrm{C}$. For dry reforming, there was the risk of carbon deposition even though there was no visible carbon deposition in reported experiments (17). An efficient approach to avoid carbon deposition is by the operation of the cell under closecircuit conditions so as to provide sufficient oxygen from the cathode side to the anode side (18-19) .

Steam reforming is another common method of improving the durability of the nickel anode that is prone to carbon deposition when operating on methane or biogas fuel. However, steam reforming decreases the total efficiency to some extent and the system is complex since an external reforming reactor is required (20). 
The anode recirculation is also an effective strategy against carbon deposition and the overall fuel utilisation and efficiency is improved if the fuel is recycled (21-22). Powell et al. reported that the overall fuel utilization was $93 \%$, which was much higher than the single-pass fuel utilization of 55\% (23). The cell exhaust gases provide the energy for the endothermic steam and dry reforming. Another advantage of using biogas in solid oxide fuel cells is that the heat generated from the electrochemical reaction is a good source for the reforming reaction.

In this paper, anode recirculation was applied to obtain a simulated biogas composition and the calculation was based on a typical composition of $63 \% \mathrm{CH}_{4}$ and $37 \% \mathrm{CO}_{2}$ (24). The simulated biogas consisting of $36 \% \mathrm{CH}_{4}, 36 \% \mathrm{CO}_{2}, 4 \% \mathrm{CO}, 4 \% \mathrm{H}_{2}$ and $20 \% \mathrm{H}_{2} \mathrm{O}$ was used for fuel in nickel cermet-based solid oxide fuel cells. The cell was tested at $850{ }^{\circ} \mathrm{C}$ using the above biogas at a flow rate of $30 \mathrm{ml} / \mathrm{min}$.

\section{Experimental}

$\underline{\text { Simulated biogas }}$

The original gas was composed of $63 \% \mathrm{CH}_{4}$ and $37 \% \mathrm{CO}_{2(24)}$, assuming that $80 \% \mathrm{CH}_{4}$ was oxidized into $\mathrm{CO}_{2}$ and $\mathrm{H}_{2} \mathrm{O}$.

$$
\mathrm{CH}_{4}+2 \mathrm{O}_{2} \rightarrow \mathrm{CO}_{2}+2 \mathrm{H}_{2} \mathrm{O}
$$

Unused $\mathrm{CH}_{4}(20 \%)$ decomposes into carbon and hydrogen, and consequently the carbon reacted with the carbon dioxide to produce carbon monoxide.

$$
\begin{aligned}
& \mathrm{CH}_{4} \rightarrow \mathrm{C}+\mathrm{H}_{2} \\
& \mathrm{C}+\mathrm{CO}_{2} \rightarrow \mathrm{CO}
\end{aligned}
$$

Electrochemically, carbon monoxide was oxidised into carbon dioxide and hydrogen was oxidized into $\mathrm{H}_{2} \mathrm{O}$.

$$
\begin{aligned}
\mathrm{CO}+\mathrm{O}_{2} & \rightarrow \mathrm{CO}_{2} \\
\mathrm{H}_{2}+\mathrm{O}_{2} & \rightarrow \mathrm{H}_{2} \mathrm{O}
\end{aligned}
$$

It was supposed that the gases, after the electrochemical reaction, would reach an equilibrium state at $900{ }^{\circ} \mathrm{C}$. These gases were calculated by the software HSC 5.1. The off gas was recirculated and $25 \%$ was added into the original mixture of $\mathrm{CH}_{4}$ and $\mathrm{CO}_{2}$. The newly obtained gas composition was subjected to $80 \%$ fuel utilization and $25 \%$ recirculation until the off gas reached a constant composition with the input gas level. The final gas composition was slightly changed and rounded into $36 \% \mathrm{CH}_{4}, 36 \% \mathrm{CO}_{2}$, $4 \% \mathrm{H}_{2}, 4 \% \mathrm{CO}$ and $20 \% \mathrm{H}_{2} \mathrm{O}$. The calculation of the simulated biogas composition was described in detail elsewhere(25).

\section{Cell fabrication and electrochemical test}

The preparation of an anode-supported cell consisting of a NiO-YSZ anode, a YSZ electrolyte and a LSM-YSZ cathode were described in details in previous paper (26) . The active area of the electrodes was $1 \mathrm{~cm}^{2}$. Gold paste and platinum paste were used for the anode and the cathode contact, respectively.

The cell was sealed on a $20 \mathrm{~mm}$ diameter alumina tube with a 552 cermo sealant. A smaller alumina tube was inserted into the above alumina tube to attach the wires for the anode connection and also for purging the gas on the anode surface. This inner alumina tube was fixed with a screw. The two cathode wires were connected by two springs. The alumina tubes were joined with Swagelok fittings. Finally, the jig with the cell and the alumina tubes was put into a vertical furnace, with the anode on bottom and the cathode 
on top. A thermocouple was placed $1 \mathrm{~cm}$ from the anode surface to monitor the overall temperature. The furnace was heated from room temperature to $850{ }^{\circ} \mathrm{C}$ at $5{ }^{\circ} \mathrm{C} / \mathrm{min}$ ramp rate. The cell was reduced in hydrogen, provided from a cylinder, until the open circuit voltage of the cell was constant value. The current-voltage curve of the cell supplied with $30 \mathrm{ml} / \mathrm{min}$ of hydrogen and $50 \mathrm{ml} / \mathrm{min}$ of air was collected on Solartron 1280B with a 20 $\mathrm{mV}$ scan rate. And then the cell ran at $100 \mathrm{~mA} \mathrm{~cm}^{-2}$ current load for 24 hours in hydrogen. The gas was switched to the simulated biogas with a total flow rate of $30 \mathrm{ml} / \mathrm{min}$. At the same time, the cathode was supplied with $50 \mathrm{ml} / \mathrm{min}$ of ambient air. According to the current-voltage curve, the cell was operating at $100 \mathrm{~mA} \mathrm{~cm}^{-2}, 300 \mathrm{~mA} \mathrm{~cm}$ and $500 \mathrm{~mA}$ $\mathrm{cm}^{-2}$ load at each current level for 16 hours, respectively. The current-voltage curves were tested after the durability experiments.

The microstructure of the cell was recorded on a Scanning Electron Microscope Jeol JSM-5600.

\section{Results and discussion}

Figure 1 shows the curves of gas components as a function of temperature ranging from $100{ }^{\circ} \mathrm{C}$ to $900{ }^{\circ} \mathrm{C}$ at pressure $=0.1 \mathrm{MPa}$ using an original biogas of $63 \% \mathrm{CH}_{4}$ and $37 \% \mathrm{CO}_{2}$, or the simulated biogas. It can be seen in Figure 1 (a) that there is carbon coking between $100{ }^{\circ} \mathrm{C}$ and $900{ }^{\circ} \mathrm{C}$ using a biogas with $63 \% \mathrm{CH}_{4}$ and $37 \% \mathrm{CO}_{2}$, but there is no carbon deposition for the simulated biogas (Figure 1(b)) at the temperature range of $720{ }^{\circ} \mathrm{C}$ to $900{ }^{\circ} \mathrm{C}$ (ie, the operating temperatures of the solid oxide fuel cells). The trend of the curves shows that concentrations of hydrogen and carbon monoxide increase remarkably up to $800{ }^{\circ} \mathrm{C}$. This suggests that the reforming reaction, either steam reforming or dry reforming or both, is the prevailing reaction, substantiated by the hydrogen concentration reaching a maximum of $750{ }^{\circ} \mathrm{C}$. Above this temperature, the increase in concentration of carbon monoxide and water is considered to be produced from the shift reaction by consuming hydrogen and carbon dioxide. The temperature range of $750{ }^{\circ} \mathrm{C}$ to $850{ }^{\circ} \mathrm{C}$ would appear to be optimal if the highest production of hydrogen is expected.
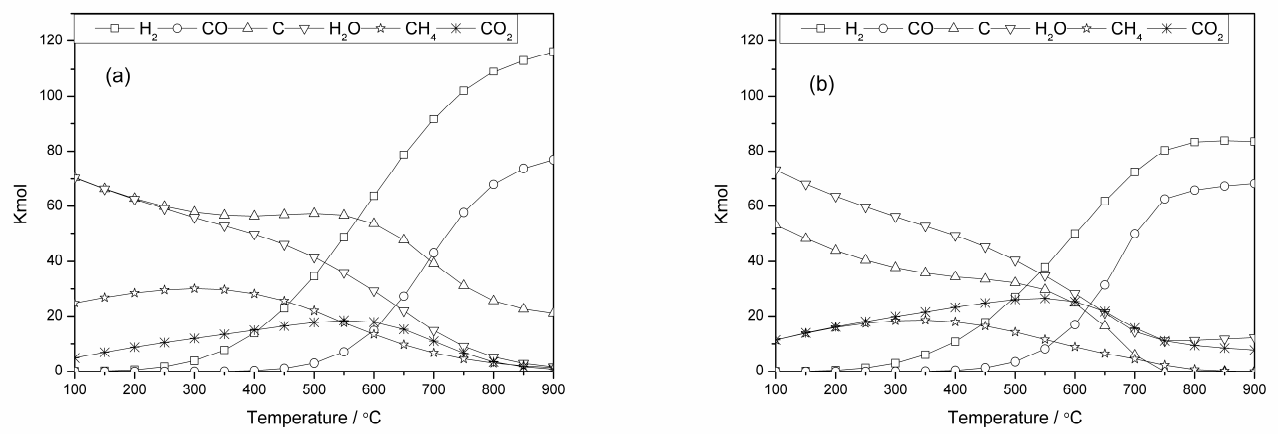

Figure 1 Equilibrium gases composition as a function of reaction temperature with an original gascomposition of (a) $63 \% \mathrm{CH}_{4}$ and $37 \% \mathrm{CO}_{2}$, and (b) simulated biogas composition of $36 \% \mathrm{CH}_{4}, 36 \% \mathrm{CO}_{2}, 4 \% \mathrm{CO}, 4 \% \mathrm{H}_{2}$ and $20 \% \mathrm{H}_{2} \mathrm{O}$

Prior to measuring the performance in all experiments, the cell was allowed to operate under open circuit condition for enough time to reach an equilibrium state. If there was a constant steam level, it was considered to be adequate equilibrium time for performance testing. 
The current-voltage and current-power curves are presented in Figure 2. The open circuit voltage of the cell in hydrogen is $1.12 \mathrm{~V}$, whilst the value in biogas is $1.01 \mathrm{~V}$ at a temperature of $850{ }^{\circ} \mathrm{C}$. Before the durability test, the cell performance using biogas fuel is close to that using hydrogen fuel, which is $1191 \mathrm{~mW} \mathrm{~cm}^{-2}$. The deviation of the cell performance in hydrogen and biogas mostly comes from the difference of the open circuit voltage in these two fuels, which is shown clearly in current-voltage curves. After the durability test, the maximum power density dropped to $856 \mathrm{~mW} \mathrm{~cm}^{-2}$. The decrease in the cell performance in biogas after the durability test is probably due to the limitation on the high current density, which may be caused by the insufficient supply of the fuels either biogas at the anode or air at the cathode.

The main difference between the theoretical calculation (shown in Figure 1) and the experimental results (shown in Figure 2) is the conversion rate of methane. There is still some methane left in practical experiments, as not all the methane is consumed. Water steam and solid carbon gradually decrease with increasing temperature, and are substituted by the same products shown in Figure 1. The formed solid carbon is consumed at temperature above $720{ }^{\circ} \mathrm{C}$ according to the calculated equilibrium composition.

The cell voltage was stable over the whole tested period. A clear change in the cell behavior was found after switching to biogas. After a polarisation experiment was performed, a significant performance loss of the cell leading to fatal failure was observed. A starvation of hydrogen and carbon monoxide can lead to nickel-reoxidation in some regions of the anode, which can finally cause the catastrophic failure of the cell.

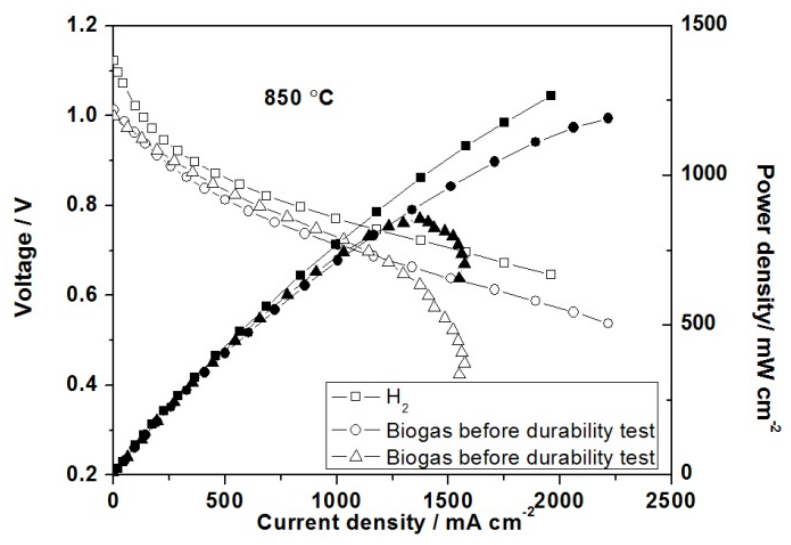

Figure 2 Current-voltage and Current-power density curves of the nickel anode-supported cell using hydrogen or simulate biogas fuel tested at $850{ }^{\circ} \mathrm{C}$, the cell performance in biogas before and after the durability test were both recorded 


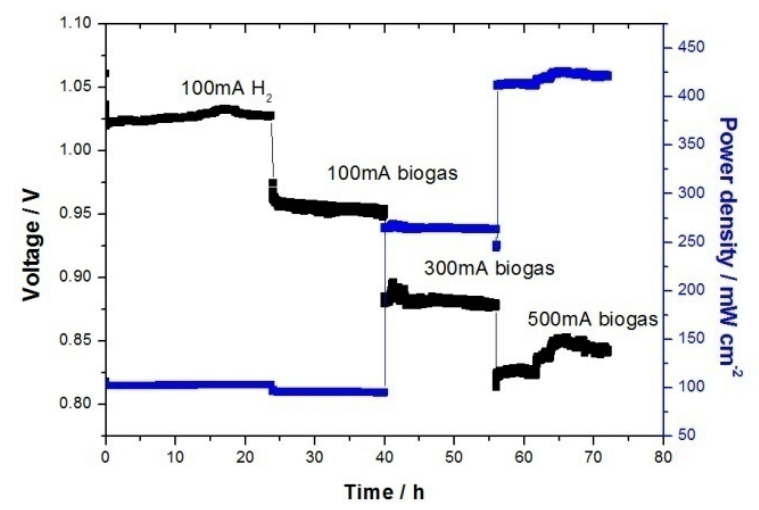

Figure 3 the durability test of the cell operating in hydrogen or biogas

Figure 3 presents the durability test of the cell running in hydrogen or biogas at different current loads. The first test was operated in pure hydrogen with a current load of $100 \mathrm{~mA} \mathrm{~cm}^{-2}$ for 24 hours. An improvement in performance over time was observed due to an activation process at a current load in hydrogen, the voltage was $1.02 \mathrm{~V}$ and increased gradually to $1.03 \mathrm{~V}$ after the 24 hours of activation. The gas was changed into simulated biogas and the cell behavior in biogas at $100 \mathrm{~mA} \mathrm{~cm}^{-2}, 300 \mathrm{~mA} \mathrm{~cm}^{-2}$ and 500 $\mathrm{mA} \mathrm{cm} \mathrm{cm}^{-2}$ was recorded as well the total testing time for each level was 16 hours. The power densities were $95 \mathrm{nmW} \mathrm{cm} 264 \mathrm{nmW} \mathrm{cm}^{-2}$ and $411 \mathrm{nmW} \mathrm{cm}$ at each level, respectively. It was noticed that the power density at $500 \mathrm{~mA} \mathrm{~cm}^{-2}$ increased from 411 $\mathrm{mW} \mathrm{cm}{ }^{-2}$ to $425 \mathrm{~mW} \mathrm{~cm}^{-2}$ during the test. The fuel utilization at each level was $1.5 \%$, $4.3 \%$ and $7.3 \%$. These values are much lower than the expected value of $80 \%$ in the calculation and need to be improved. The present flow rate of biogas is controlled to 30 $\mathrm{ml} / \mathrm{min}$ and can be lowered to get a better fuel utilization. Alternatively new cell structures or components could be developed to operate in biogas fuel.

After electrochemical tests, the microstructure of the cell was tested by SEM and the image was shown in Figure 4. A porous anode with well distributed nickel and YSZ particles and a thin layer YSZ electrolyte were observed. It seemed that the porosity of LSM-YSZ cathode is not sufficient for the gas diffusion and this might be why high concentration resistance was observed after the durability test. In order to get better cell performance, the cathode structure can be further optimized.

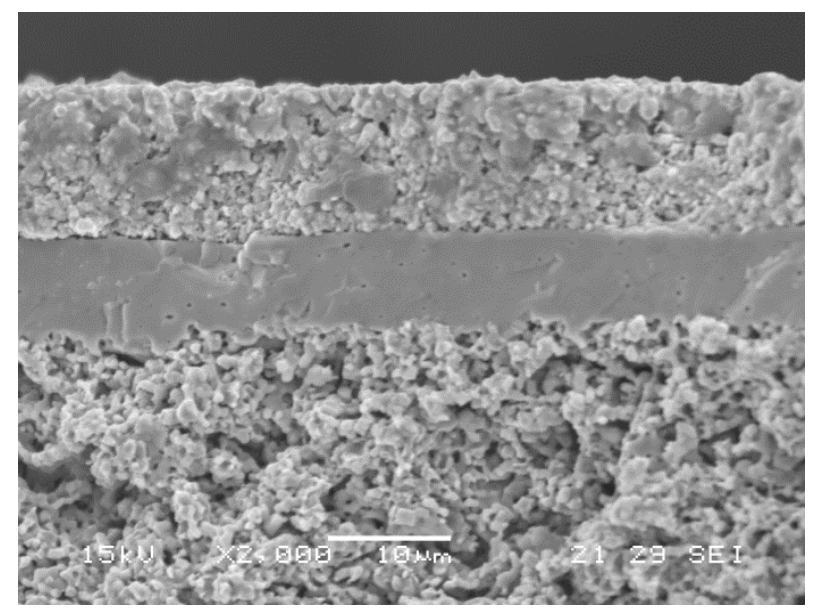

Figure 4 Microstructure of the cell with a Ni-YSZ supported anode, a YSZ thin electrolyte and a LSM-YSZ cathode after being tested in simulated biogas. 


\section{Conclusion}

We have demonstrated that nickel-based solid oxide fuel cell can utilise simulated biogas having a composition of $36 \% \mathrm{CH}_{4}, 36 \% \mathrm{CO}_{2}, 4 \% \mathrm{H}_{2}, 4 \% \mathrm{CO}$ and $20 \% \mathrm{H}_{2} \mathrm{O}$ as a fuel to produce electrical power without carbon deposition. Supplied with a $30 \mathrm{ml} / \mathrm{min}$ of the simulated biogas, the cell ran stably at loads of $100 \mathrm{~mA} \mathrm{~cm}^{-2}, 300 \mathrm{~mA} \mathrm{~cm}$ and 500 $\mathrm{mA} \mathrm{cm} \mathrm{c}^{-2}$ for 16 hours at each level. The practical fuel utilisation needs to be improved to get the proposed $80 \%$ fuel utilization.

\section{Reference}

1. K. M. Dunst et al., Solid State Ionics, 251, 70 (2013).

2. J. Van herle, F. Marechal, S. Leuenberger, D. Favrat, J. Power Sources, 118, 375 (2003).

3. I. Wheeldon, C. Caners, K. Karan, B. Peppley, Int. J. Green Energy, 4, 221 (2007).

4. $\quad$ A. Lanzini, P. Leone, Int. J. Hydrogen Energy, 35, 2463 (2010).

5. J. Staniforth, K. Kendall, J. Power Sources, 71, 275 (1998).

6. J. Staniforth, M. Ormerod, Green Chem., 3, G61 (2001).

7. J. Staniforth, R. M. Ormerod, Catal. Lett., 81, 19 (2002).

8. V. Chiodo, F. Urbani, A. Galvagno, N. Mondello, S. Freni, J. Power Sources, 206, 215 (2012).

9. D. M. Murphy, A. E. Richards, A. Colclasure, W. Rosensteel, N. P. Sullivan, Ecs Trans., 35, 2653 (2011).

10. D. M. Murphy, A. E. Richards, A. Colclasure, W. A. Rosensteel, N. P. Sullivan, J. Renew. Sustain. Energy, 4, (2012).

11. T. Ishihara, T. Yamada, T. Akbay, Y. Takita, Chem. Eng. Sci., 54, 1535 (1999).

12. T. Yamada, Y. Hiei, T. Akbay, T. Ishihara, Y. Takita, Solid State Ionics, 113, 253 (1998).

13. Y. Hiei, T. Ishihara, Y. Takita, Solid State Ionics, 86-8, 1267 (1996).

14. V. Eveloy, Imece2009, 6, 627 (2010).

15. C. S. Lau, D. Allen, A. Tsolakis, S. E. Golunski, M. L. Wyszynski, Biomass Bioenerg., 40, 86 (2012).

16. S. T. Naumann, C. Myren, J. Power Sources, 56, 45 (1995).

17. Y. Shiratori, K. Sasaki, J. Power Sources, 180, 738 (2008).

18. D. J. Moon, J. W. Ryu, Catal. Today, 87, 255 (2003).

19. D. J. Moon, J. M. Park, J. S. Kang, K. S. Yoo, S. I. Hong, J. Ind. Eng. Chem., 12, 149 (2006).

20. A. L. Dicks, J. Power Sources, 71, 111 (1998).

21. V. Eveloy, M. Daoudi, Imece 2008, 387 (2009).

22. S. Farhad, Y. Yoo, F. Hamdullahpur, J. Power Sources, 195, 1446 (2010).

23. M. Powell, K. Meinhardt, V. Sprenkle, L. Chick, G. McVay, J. Power Sources, 205, 377 (2012).

24. S. Rasi, A. Veijanen, J. Rintala, Energy, 32, 1375 (2007).

25. S. Gamble, D. Neagu, J. T. S. Irvine, Ecs Trans., 57, 1527 (2013).

26. C. Jiang, J. Ma, A. D. Bonacorroso, J. Irvine, Energ. Environ. Sci., 5, 6973 (2012). 